\title{
Environmental Assessment of Vehicular Emission in Port-Harcourt City, Nigeria
}

\author{
*Nkwocha A.C., Ekeke I.C., Kamalu C.I.O., Kamen F.L., Uzondu F.N., Dadet W.P' ${ }^{1}$, Olele \\ P.C ${ }^{2}$.
}

*Department of Chemical Engineering, Federal University of Technology, P M B 1526, Owerri, Nigeria.

${ }^{1}$ Department of Chemical/Petrochemical Engineering, Rivers State University of Technology, P.M.B, 5030, Port Harcourt,

Nigeria.

${ }^{2}$ Department of Mechanical Engineering, Federal University of Technology, P M B 1526, Owerri, Nigeria.

\begin{abstract}
Port Harcourt is a coastal city located in the Niger Delta region of Nigeria, with very short dry season and long heavy rainy season periods. The objective of this study was to assess air pollution level from vehicular emission during the rainy season period. Three locations in the city noted for high traffic congestion were selected for the study. Air sampling in these locations were carried out for 11 days, covering peak and off peak periods. The following air pollutants were measured namely; nitrogen oxides $\left(\mathrm{NO}_{x}\right)$, sulphur oxides $\left(\mathrm{SO}_{x}\right)$, carbon monoxide $(\mathrm{CO})$ and unburnt hydrocarbons $\left(C_{x} H_{y}\right)$, as well as climatic elements - ambient temperature and relative humidity. The air pollutant levels obtained were compared with local and international standards. CO complied with international standard, but exceeded local standard. There is need for effective air pollution monitoring and control, this will go a long way to reduce the health risk associated with air pollution in the city.
\end{abstract}

Keywords - ambient, air pollution, coastal city, congestion, exposure.

\section{INTRODUTION}

Environmental problems constitute one of the key challenges of the $21^{\text {st }}$ century, and urban air pollution is a major health hazard worldwide (Avogbe et al., 2011). Air pollution results from four main sources namely; industrialization, tobacco smoking, domestic cooking and vehicular or machinery fuel combustion (Tanimowo, 2000). However, the level of air pollution depends on a country's technology and pollution control. All over Africa, studies have shown that air pollution from the four sources adversely affect people's respiratory health (Theron et al., 1994; Tanimowo, 1995; Mohammed et al., 1995; Hsairi et al. ,1996; Nriagu et al., 1996; Shamssain and Shamissian
1997; Mengasha and Bekele 1998; Uko et al., 1998; Tanimowo, 1998).

The composition of the ambient air is complex and depends on the equality of fuel, the type of engine, and engine maintenance (leong et al., 2002). Motor vehicles in developing countries cause serious air pollution because they are concentrated in a few large cities, besides, many are in poor mechanical conditions, and few if any emission standards exist. Vehicular emissions continue to be a major threat to environmental health, which is expected to increase reasonably as automobile ownership increase globally (Abam and Unachukwu, 2009). Vehicle exhaust generally contains poly cyclic aromatic hydrocarbons (PAHs), particles, carbon monoxide (CO), nitrogen oxides $\left(\mathrm{NO}_{\mathrm{x}}\right)$ and volatile organic compounds (VOCs) such as benzene. Diesel-powered engines are the major source of particle, whereas two stroke motor bikes and petrol powered cars emit high levels of VOCs.

$\mathrm{CO}$ is different from most other air pollutants in its acute health effects. Benzene has been classified by the International Agency for Research on Cancer (IARC) as a human carcinogen (IARC,1997). In addition, exposure to benzene has been associated with health effects including hematopoietic disorders such as bone marrow deficiency and acute myetogenous leukemia in both rodents and humans (Hayes et al., 2001).

Port Harcourt City has acquired national and international prominence, because it is the pivot of Nigeria's oil and gas activities, and a state capital. It is therefore not surprising that there has been a great influx of people into the city in recent years (Nkwocha et al., 2008; Nkwocha et al., 2010), with attendant increase in population. In Nigeria, much attention is given to general industrial pollution and pollution in oil industries, with little reference to damage of pollution caused by mobile transportation sources of air 
pollution (Faboye, 1997; Iyoha, 2001; Magbagbeola, 2001). Limited road network, and increase in per capita vehicle ownership as a result of economic growth, has led to high traffic congestion on city roads and increased the risk of pollution from mobile transportation sources. The situation is worsened by the fact that most of the vehicles are older models, imported used vehicles, and there is no exhaust emission control (Mustapha, 2011). The consequence is increased health risk on human population.

Port Harcourt is a coastal city located in the Niger Delta region of Nigeria, with very short dry season and long heavy rainy season periods. The peak rainfall occurs in the month of September. The objective of this study was to assess vehicular pollution levels in the city during the rainy season period.

\section{MATERIALS AND METHOD}

The research involved the collection of data on the following air quality parameters; $\mathrm{CO}, \mathrm{NO}_{\mathrm{x}}, \mathrm{SO}_{\mathrm{x}}$, and $\mathrm{C}_{\mathrm{x}} \mathrm{H}_{\mathrm{y}}$. The climatic elements sampled were the ambient temperature $\left({ }^{\circ} \mathrm{C}\right)$, and relative humility $(\%)$. Three highly notorious high traffic density junctions in the city were selected for the study namely;

$>$ Rumuokoro Round - about (location A)

$>$ First Artillery Junction, along Aba Road express way (location B)

$>$ Nkpogu Junction, along Trans-Amadi Road (location C).

Measurement of the selected pollutants at the locations was carried out in three (3) time periods, for the duration of three working days of the week. They are as follows:

$>7.30 \mathrm{am}-9.00 \mathrm{am}$ (Morning peak hours)

$>1.00-3.00 \mathrm{pm} \quad$ (Off peak)

$>\quad 5.00 \mathrm{pm}-7.00 \mathrm{pm} \quad$ (Evening peaks hours).

The peak hours are periods of high traffic congestion. This occurs mainly in the morning, and evening hours, while the off peak is period of low traffic, which occurs in the afternoon. Measurement of air quality parameters was carried out using the Testo 350XL Emission Analyzer. The climactic elements - temperature and relative humidity were obtained using Thermo- hydrometer- IT202 .The study was conducted over a period of 11 days, between 20th August and $5^{\text {th }}$ September, 2013.

\section{RESULTS AND DISCUSSION}

The average emission estimate and climatic elements for the different locations and periods are presented in Table 1, while Figs 1-4 compare graphically the concentration of the air quality parameters for the different locations. As can be observed, all the air quality parameters investigated where generally detected. However, in a previous study by Utang and Peterside (2011), $\mathrm{SO}_{\mathrm{x}}$ were generally not detected. Location $\mathrm{B}$ experienced higher concentrations of $\mathrm{NO}_{\mathrm{x}}$ and $\mathrm{CO}$ at evening peak periods and lower concentration of $\mathrm{C}_{\mathrm{x}} \mathrm{H}_{\mathrm{y}}$ at morning periods, while the highest and lowest concentrations of $\mathrm{SO}_{\mathrm{x}}$ were detected at location $\mathrm{C}$ during off peak and evening peak periods respectively

On the other hand, high concentrations of $\mathrm{NO}_{\mathrm{x}}, \mathrm{CO}$, and $\mathrm{C}_{\mathrm{x}} \mathrm{H}_{\mathrm{y}}$ were prominent at evening peak periods. From Table 1 , the $\mathrm{NO}_{\mathrm{x}}$ concentrations for all the locations were above the limit of $0.04-0.06 \mathrm{ppm}$ set by local (Nigeria) standard (FEPA,1991)and 0.053ppm set by International standards, for all the locations and periods, except location $\mathrm{C}$ during peak periods. The level of $\mathrm{CO}$ was within local standard (10-20ppm) for the off peak period, but exceeded at peak periods in some locations namely - location B at morning and evening peak, locations $\mathrm{A}$ and $\mathrm{C}$ at evening peak. However, it is noteworthy that the $\mathrm{CO}$ levels were within international standard of $35 \mathrm{ppm}$.

Climatic elements and variations in pollutant concentration As the relative humidity of sampled locations rose, temperature decreased, and the concentration of the pollutants decreased across each location. The highest variation of relative humidity and temperature occurred during morning and off peak periods respectively. All temperatures measured were within the maximum temperature range for the city.

Generally, the air pollutants exhibited the highest variation in concentration across location during the morning period and the lowest during off-peak periods .While $\mathrm{CO}$ varied most in concentration across locations and periods (standard deviation 4.48-6.62), $\mathrm{SO}_{\mathrm{x}}$ generally did not show much variation. This is in agreement with an earlier study (Utang and Peterside, 2011). Thus, $\mathrm{CO}$ and $\mathrm{SO}_{\mathrm{x}}$ accounted for the highest and lowest variations respectively, in air quality parameter concentration during all periods in all the locations.

\section{General assessment of pollutant level}

From the results obtained the variations in the concentration of pollutants can be attributed to weather conditions, mode of operation of traffic, quality of vehicle (that is, age and maintenance routine), and fuel type vehicle (that is, diesel or petrol) (Faize and Stum, 2000; Rouphail et al., 2001; Udeozor and Nzeakor, 2012). Activities common to the different location studied include, intersection of road, traffic lights, queues, cars packing due to engine being temporarily switched off and driving that involves repeated acceleration, idling, and deceleration cycles.

The high concentrations of $\mathrm{NO}_{\mathrm{x}}, \mathrm{CO}$ and $\mathrm{C}_{\mathrm{x}} \mathrm{H}_{\mathrm{y}}$ observed in the evening peak periods could be attributed to constantly

Page | 907 
high ambient temperatures and traffic congestion. It has been reported that high ambient temperatures are associated with increase in exhaust emissions, which are further influenced by air conditioner usage, causing high engine load (Utang and Peterside, 2011). This, coupled with the high temperature of the vehicle combustion chambers, $\mathrm{NO}_{\mathrm{x}}$ could be high as indicated by the result. Similarly, at peak periods characterized by deceleration, there is excess fuel in the combustion chamber, so $\mathrm{C}_{\mathrm{x}} \mathrm{H}_{\mathrm{y}}$ are increased (Colls, 2002; Abhisheck and Colls, 2010). Hydrocarbon emissions can be influenced by ambient temperatures. The high concentration experienced in the afternoon off peak periods could be as a result of evaporative emissions from running losses and diurnal ways (Heywood, 1997). CO air concentrations are generally high in areas with heavy traffic congestion, which characterize the peak periods. The generally low levels of $\mathrm{SO}_{\mathrm{x}}$ in all the locations attest to the fact that the fuels used are low in sulphur. However, the isolated case of high concentration observed in location $\mathrm{C}$ at off peak, could be due to other industrial activities taking place near the area.

The adverse health effects associated with the high concentration of these pollutants are great. $\mathrm{NO}_{\mathrm{x}}$ is responsible for immune system impartment, exacerbation of asthma and chronic respiratory diseases, reduced lung function and cardiovascular disease (Schwela, 2000); while $\mathrm{CO}$ reduces oxygen flow in blood stream, exacerbates coronary heart diseases, and at low concentrations can impair concentration and neuro-behavioural function (Udeozor and Nzeakor, 2012).

\section{CONCLUSION}

The study revealed that the concentration of $\mathrm{NO}_{\mathrm{x}}$ in all the locations did not comply with local and international standards. Though, the concentration of $\mathrm{CO}$ was within international standard, it did not meet local standard. In view of the health effects of these pollutants, it implies that the health of roadside artisans, street hawkers, traffic workers, traders and others who are stationed near and around these location, and off course, city dwellers are at risk. There is need for effective air pollution monitoring and control programmes for mobile and stationary emission sources. In addition, improved road net work and traffic control will ease congestion and associated air pollution problems.

Table.1: Average concentration of ambient air pollutants at various locations and periods

\begin{tabular}{|l|l|l|l|l|l|l|l|}
\hline Period & Location & NOx$(\mathbf{p p m})$ & $\mathbf{S O x}(\mathbf{p p m})$ & $\mathbf{C O}(\mathbf{p p m})$ & $\mathbf{C x H y}(\mathbf{L E L})$ & $\mathbf{R H}(\mathbf{\%})$ & Temp $\left({ }^{\mathbf{0}} \mathbf{C}\right)$ \\
\hline Morning Period & $\mathrm{A}$ & 0.89 & 0.012 & 13.37 & 0.41 & 72.7 & 30.2 \\
\hline & $\mathrm{B}$ & 1.16 & 0.011 & 21.8 & 0.24 & 69.1 & 32.6 \\
\hline & $\mathrm{C}$ & 0.53 & 0.009 & 11.43 & 0.36 & 70.6 & 32.5 \\
\hline & Mean & $\mathbf{1 . 0 5}$ & $\mathbf{0 . 0 1 2}$ & $\mathbf{1 7 . 4 6}$ & $\mathbf{0 . 3 7}$ & $\mathbf{7 0 . 6}$ & $\mathbf{3 2 . 5}$ \\
\hline & Std Dev & $\mathbf{0 . 1 4}$ & $\mathbf{0 . 0 0}$ & $\mathbf{6 . 6 2}$ & $\mathbf{0 . 1 0}$ & $\mathbf{0 . 8 7}$ & $\mathbf{0 . 3 6}$ \\
\hline & $\mathrm{A}$ & 1.1 & 0.01 & 14.43 & 0.26 & 72.9 & 30.4 \\
\hline & $\mathrm{B}$ & 1.2 & 0.01 & 18.07 & 0.41 & 69.6 & 32.1 \\
\hline & $\mathrm{C}$ & 0.31 & 0.08 & 16.07 & 0.4 & 70.8 & 31.5 \\
\hline & Mean & $\mathbf{0 . 4 2}$ & $\mathbf{0 . 0 1 1}$ & $\mathbf{1 6 . 8 4}$ & $\mathbf{0 . 3 8}$ & $\mathbf{7 1 . 1}$ & $\mathbf{3 1 . 3 3}$ \\
\hline & Std Dev & $\mathbf{0 . 0 7}$ & $\mathbf{0 . 0 0}$ & $\mathbf{4 . 4 8}$ & $\mathbf{0 . 1 7}$ & $\mathbf{0 . 2 5}$ & $\mathbf{0 . 5 0}$ \\
\hline & $\mathrm{A}$ & 1.17 & 0.013 & 24.57 & 0.44 & 74.3 & 29.7 \\
\hline & $\mathrm{B}$ & 1.29 & 0.011 & 24.57 & 0.44 & 74.3 & 29.7 \\
\hline & $\mathrm{C}$ & 0.42 & 0.007 & 23.03 & 0.51 & 70.3 & 32.00 \\
\hline & Mean & 1.22 & 0.008 & 22.02 & 0.42 & 71.13 & 31.5 \\
\hline & Std Dev & $\mathbf{0 . 1 0}$ & $\mathbf{0 . 0 0}$ & $\mathbf{6 . 0 6}$ & $\mathbf{0 . 0 8}$ & $\mathbf{0 . 4 0}$ & $\mathbf{0 . 3 6}$ \\
\hline & $\begin{array}{l}\text { Grand } \\
\text { Mean }\end{array}$ & $\mathbf{0 . 9 7}$ & $\mathbf{0 . 0 1}$ & $\mathbf{1 8 . 6 1}$ & $\mathbf{0 . 4 0}$ & $\mathbf{7 1 . 0 0}$ & $\mathbf{3 1 . 5 0}$ \\
\hline & $\begin{array}{l}\text { Grand } \\
\text { Std Dev }\end{array}$ & $\mathbf{0 . 2 7}$ & $\mathbf{0 . 0 0}$ & $\mathbf{5 . 7 3}$ & $\mathbf{2 . 2 7}$ & $\mathbf{1 . 8 9}$ & $\mathbf{1 . 1 5}$ \\
\hline & & NA & $\mathbf{0 . 0 1}$ & $\mathbf{1 0 . 0 0}$ & NA & NA & NA \\
\hline
\end{tabular}

$\mathrm{LEL}=$ Lower emissible limit $\quad$ ppm $=$ parts per million $\quad$ FEPA = Federal Environmental Protection Agency

$\mathrm{NA}=$ not available 


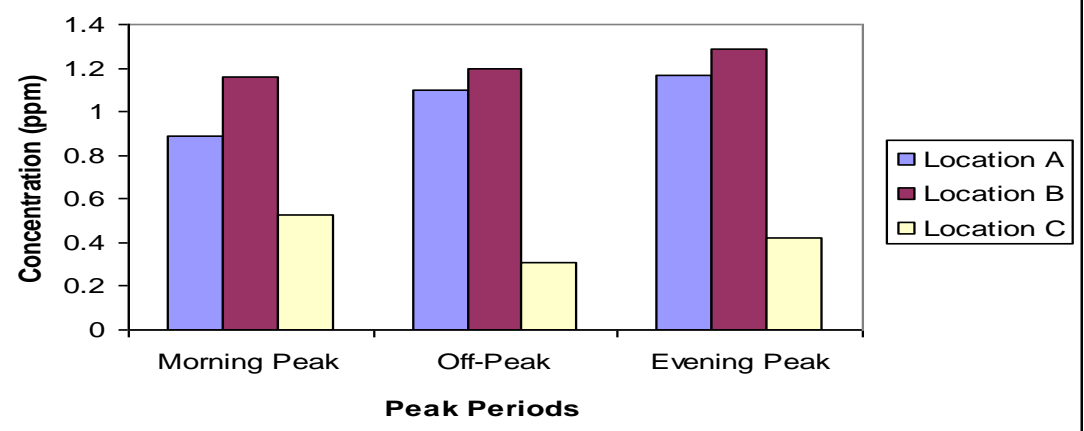

Fig.1 Average concentration of $\mathrm{NO}_{x}$
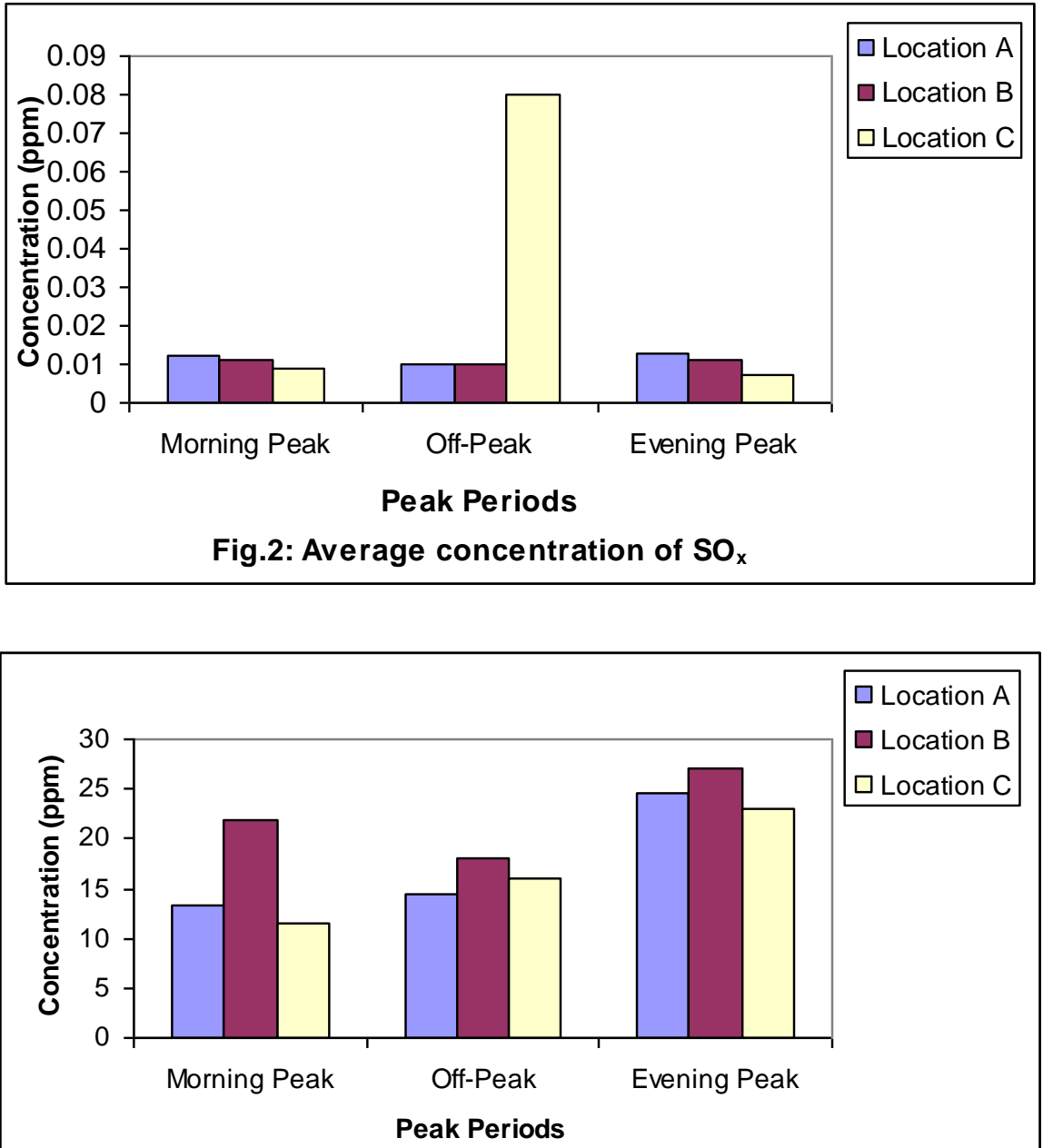

Fig.3: Average concentration of $\mathrm{CO}$ 


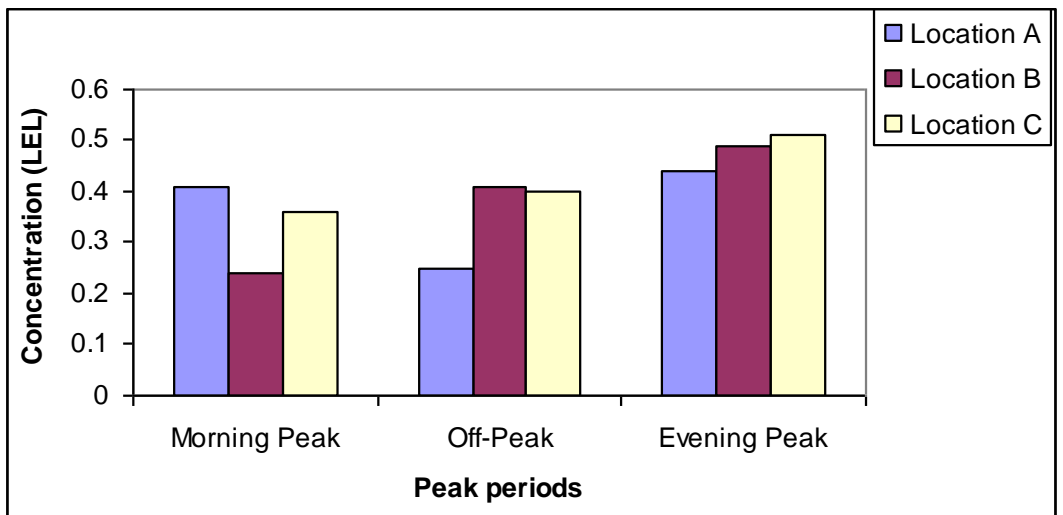

Fig.4: Average concentration of $\mathrm{C}_{\mathrm{x}} \mathrm{H}_{\mathrm{y}}$

\section{REFERENCES}

[1] F.I. Abam, and G.O. Unachukwu. Vehicular emissions and air quality standard in Nigeria. European Journal of Scientific Research, Vol.34, No. 4, pp.550-560, 2009.

[2] T. Abhishek, and J. Colls. Air pollution measurement, modelling and migration, London Rutledge, 2010.

[3] P.H. Avogbe, L. Ayi-Fanou, B.I. Cachon, N. Chebi, A. Debende, D. Dewaele, F. Aiss, F. Cazier, and A. Sanni. Haematological changes among Beninese motor bike taxi drivers exposed to benzene by urban air pollution. African Journal of Environmental Science and Technology , vol.5(7), pp. 464-470, 2011.

[4] J. Colls. Air pollution, London, Journal of Applied Science, 7(16):2536 -2860, 2002.

[5] O.O. Faboye. Industrial Pollution and Waste Management, In: Dimensions of Environmental Problems in Nigeria, Osuntokun A. (ed), Davidson Press, Ibadan, 1997, pp.26 - 35.

[6] I.A. Faize, and P. Stum. New directions in air pollution and road traffic in developing Countries. Atmospheric Environment, 34(27): 4745-4746, 2000.

[7] FEPA - Federal Environmental Protection Agency. Gudelines. and Standards for Environmental Control in Nigeria, 1991.

[8] R.B. Hayes, Y. Songnian, M. Doseneci, and M. Linet, M. Benzene and lympho haematopoietic malignancy in humans, Am. J. Ind. Med. 40: 117-126, 2001.

[9] J.B. Heywood. Progress in energy and combustion. An International Review Journal, University of Shefield, England, Pergamom Press, Oxford, 1977.
[10] M. Hsairi, M. Maalej, N. Achour. Respiratory effects of air pollution in two popular districts of the Greater Tunis Metropolitan Area. A case study in school environment, Tunis Med. 74:119-124, 1996.

[11] IARC Monographs on the Evaluation of Carcinogenic Risks in Humans, Overall Evaluation of Carcinogenicity. An up-dating of IARC monographs. Lyon, France, 1-42:120-122, 1977.

[12] M.A. Iyoha. Environmental effects of oil industry activities in the Nigeria economy: A theoretical analysis - Paper represented at national conference on the management of Nigeria petroleum resources, organized by the Department of Economics, Delta State University, Nigeria, 2009.

[13] S.T. Leong, S. Mutamara, and P. Laortanakul, P. Influence of Benzene emission from motorcycles on Bangkok air quality. Atmos. Environ. 36:651-661, 2002.

[14] N.O. Magbagbeola. The use of economic instruments for industrial environmental pollution abatement in Nigeria, Application to the Lagos lagoon, selected papers, Annual conferences of the Nigeria Economic Society held in Port Harcourt, Nigeria, 2001.

[15] Y.A. Mengesha, and A. Bekele Relative chronic effects of different occupational dusts on respiratory indices and health of workers in three Ethiopian factories, Am. J. Ind. Med. 34:373-380, 1998.

[16] N. Mohammed, L. Ng'ang'a, and J. Odhiambo. Home environment and asthma in kenyan school children: a case control study. Tharax. 50:74-78, 1995.

[17] B.A. Mustapha. Traffic air pollution and other risk factors for respiratory illness in school children in 
Niger Delta region of Nigeria. Environ. Hlth.

Perspect.11:1479-1482, 2011.

[18] A.C. Nkwocha, J.I. Okoye, and A.O. Agbo. Municipal solid waste management: A case study of Port Harcourt City in Rivers State, Nigeria. Journal of Environmental Research and Policies, Vol.3, No.4, p108-111, 2008.

[19] Nkwocha, A C., Okoye, J.I. and Ezigbo. C.I. (2010). Municipal solid waste disposal routing-A case study of two zones in Port Harcourt City, Rrivers State, Nigeria. International Journal of Environmental Science, Vol. 6, No. 1, pp.55-63.

[20] J. Nriagu, C. Jinabhai, R.N. Naidoo. Atmospheric lead pollution in Kwa Zulu Natal, South Africa, Sci. Total Environ.191:69-76, 1996.

[21] N.M. Rauphail, H.C. Frey, J.D. Colyar, and A. Unal. Vehicle emission and traffic measures: Exploratory analysis of field observations at signalized arterials. Paper presented at signalized materials. Paper presented at the $80^{\text {th }}$ Annual meeting of the Transportation Research Board, 2001.

[22]D. Schwela. Air pollution and health in urban areas, Review in Environmental Health. 15(12)13-24, 2000.

[23] M.H. Shamssain, and N. Shamsian. Respiratory symptoms and pulmonary function in a group of women weavers in South Africa, Am. Hum. Biol. 24:299-306, 1997.

[24] M.O. Tanimowo. The respiration effect of industrial pollution in Bacita, Kwara State Nigeria, Nig. Med. Pract. 29:8-10, 1995.

[25] M.O. Tanimowo, M.O. Air pollution and respiratory morbidity - the situation in developing countries, Zambia J. Med. Hlth Sci., 2: 14-16, 1998.

[26] M.O. Tanimowo. Air pollution and respiratory health in Africa: A review, East African Medical Journal, Vol.77, No.2 pp.71-75, 2000.

[27] A.I. Theron, G. Richard, A.S. Myer. Investigation of relative contribution of cigarette smoking and mineral dust exposure in activation of circulating phagocytes, alterations in plasma concentrations of vitamin $\mathrm{C}$, vitamin $\mathrm{E}$, and beta-carotene, and pulmonary dysfunction in South African gold miners. Occ. Environ. Med.51:564-567, 1994.

[28] O.S. Udeozor, and A.N. Nzeako. Implications of importation of used vehicles on the environment. Global Journal of Researches in Engineering, Vol.12, issue 1, Version 10, 2012.
[29] G.P. Uko, J.A. Gbadebo, and S.O. Banjoko. Carboxyhaemoglobin levels in some Lagos dwellers, a pilot study. West Afr. J. Med. 17:202-205, 1998.

[30] P.B. Utang, and K.S. Peterside. Spatio temporal variations in urban vehicular emission in Port Harcourt City, Nigeria. Ethiopian Journal of Environmental Studies and Management, Vol.4, No. 2. Pp. 38-51, 2011. 